\title{
Ten-year experience with primary ocular 'reticulum cell sarcoma' (large cell non-Hodgkin's lymphoma)*
}

\author{
MARC J SIEGEL,' JACK DALTON, ${ }^{2}$ ALAN H FRIEDMAN, \\ JAMES STRAUCHEN, ${ }^{34}$ AND CAROLYN WATSON ${ }^{3}$
}

From the Departments of ${ }^{1}$ Ophthalmology, ${ }^{2}$ Radiation Therapy, ${ }^{3}$ Pathology, and ${ }^{4}$ Neoplastic Diseases, Mount Sinai School of Medicine, New York, New York 10029, USA

SUMMARY Fourteen patients with intraocular 'reticulum cell sarcoma' (non-Hodgkin's large cell lymphoma) ranging in age from 27 to 77 are presented. All patients had evidence of vitritis with $50 \%$ showing intraretinal and/or subretinal lesions and $21 \%$ having anterior uveitis. Five of the patients developed central nervous system lesions and subsequently died. Primary radiation therapy to the eyes and CNS appears to prevent spread of the disease and improve longevity. Chemotherapy improved survival in one patient with CNS spread of disease.

Reticulum cell sarcoma (RCS) is a rare nonHodgkin's large cell lymphoma which can masquerade as chronic uveitis. This disease occurs in two broad forms, with one variety primarily involving the systemic lymph nodes, visceral organs, and uveal tract and another primarily affecting the retina, vitreous, and central nervous system (CNS). In the Rappaport classification the disease was relabelled as a histiocytic lymphoma. ${ }^{1}$ More recently surface marker studies ${ }^{2}$ have shown these cells to be of lymphoid and not histiocytic origin.

Over 100 cases $^{3-10}$ of ocular RCS have been described in the literature. Typically, the patients have been in their sixth or seventh decade when either a unilateral or bilateral painless decrease in visual acuity occurred. No sexual or racial prediliction has been noted. Invariably, ocular findings include vitreous cells and debris (Fig. 1). The retina and choroid (Fig. 2), the conjunctiva, and the optic nerve may be infiltrated by tumour. Less commonly an anterior chamber reaction or an exudative retinal detachment may be presenting sign (Fig. 3). Systemic spread is common, with the CNS being affected first (Fig. 4). It is not clear if this spread of tumour represents true metastatic disease or whether it reflects a multicentric origin of the lymphoma. Diagnosis is achieved by means of vitreous aspiration and

*Presented at the annual meeting of the American Academy of Ophthalmology in Dallas, Texas on 11 November 1987.

Correspondence to Alan H Friedman, MD Department of Ophthalmology, Box 1183, Mount Sinai School of Medicine, One Gustave L Levy Place, New York, NY 10029, USA examination of a slide prepared from the cytospin or Millipore filter of the specimen (Fig. 5).

Over the last 10 years we have had the opportunity to treat 14 patients with RCS, with a follow-up time of up to seven years. A profile of these patients, their clinical findings, and treatment is presented (Table 1).

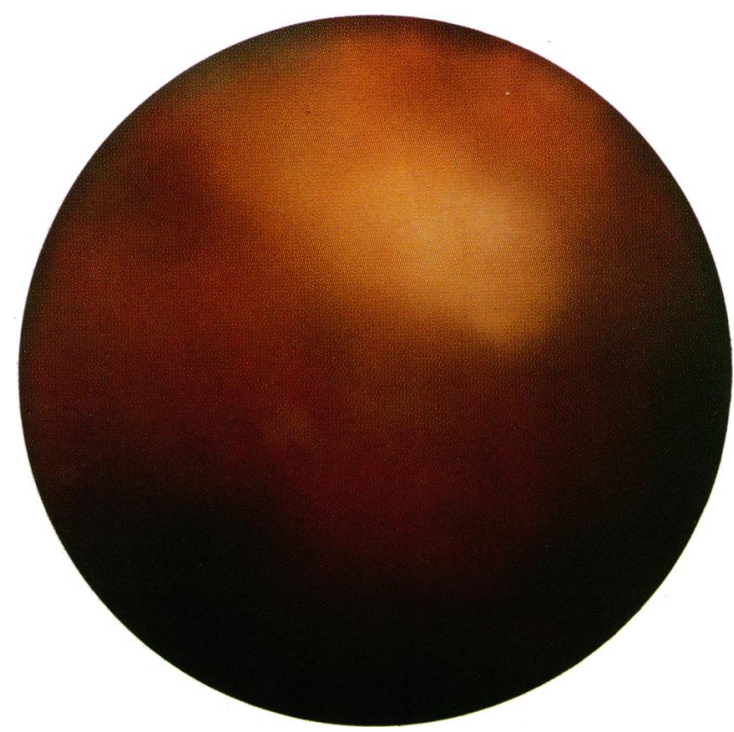

Fig. 1 Vitritis and subretinal lesions in patient with active disease. 


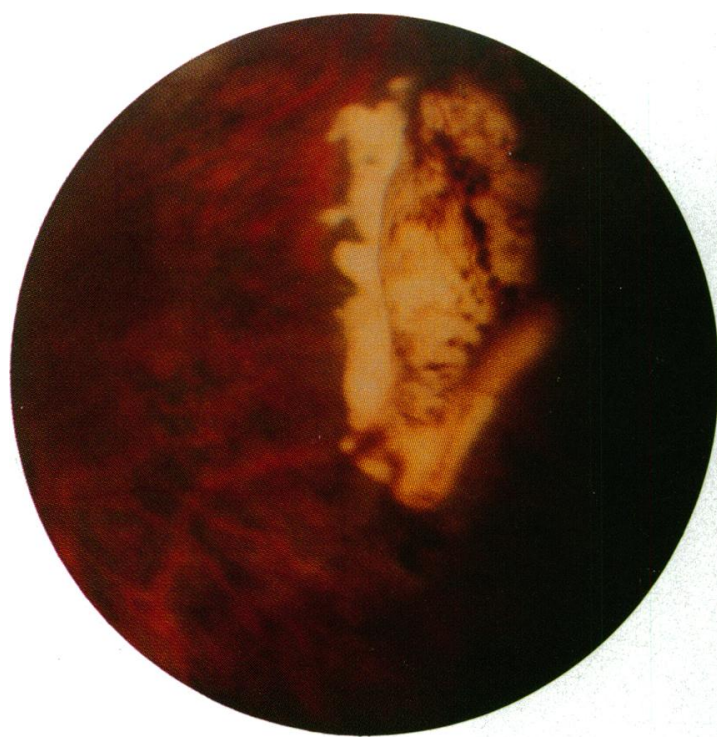

Fig. 2 Large subretinal nodule seen at initial presentation.

\section{Results}

The age at presentation ranged from 27 to 77 years, mean 65 . Nine out of 14 or $64 \%$ of the patients were women, with no black patients in our series. Disease was bilateral in $71 \%$ of the patients. There was vitritis in $100 \%$ of the patients and retinal/subretinal lesions in $50 \%$. Three of the fourteen patients had an

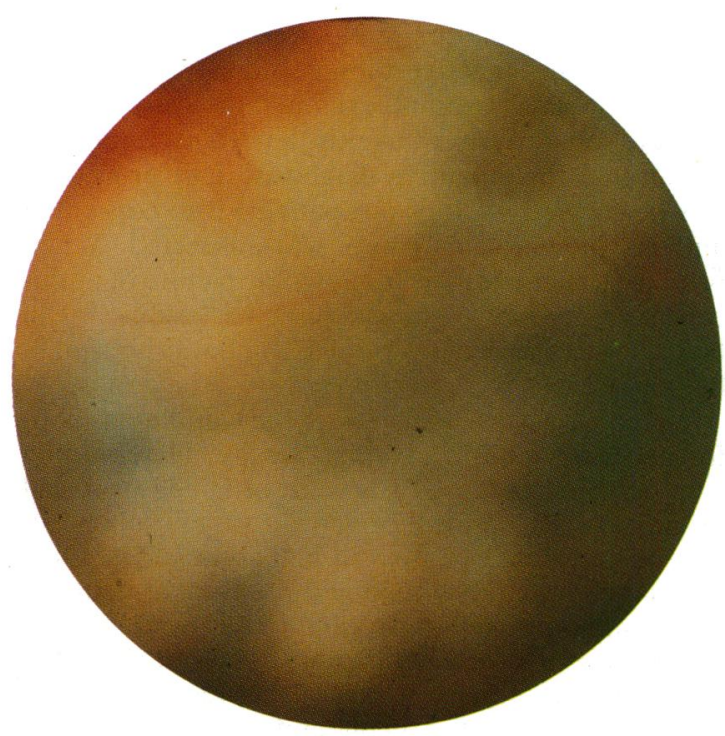

Fig. 3 Extensive vitritis and exudative detachment as presenting sign.

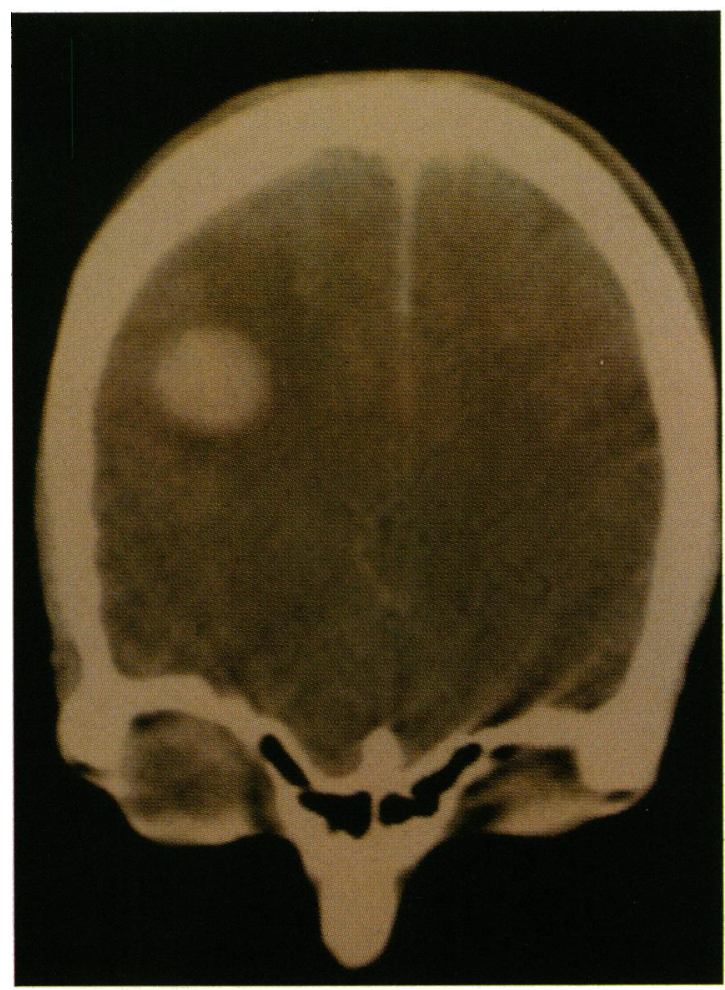

Fig. 4 Typical CNS lesion from metastatic RCS.

anterior uveitis as well, with one being moderately intense.

Initial investigations included a complete systemic evaluation with head CT scan, lumbar puncture for examination of cerebrospinal fluid, and bone marrow aspiration. Central nervous system involvement was present at the time of initial diagnosis in two cases and subsequently developed in four additional patients. All patients with CNS lesions except one died about six months after the presence of these lesions was confirmed.

The diagnosis of RCS was confirmed in 11 patients by means of a vitreous aspiration. This was performed with a 19 gauge needle introduced via the pars plana with $0.5 \mathrm{ml}$ of fluid aspirated. One patient refused any diagnostic or therapeutic manoeuvres and two patients were not suspected of harbouring RCS until the time of necropsy. Nine patients who were diagnosed by vitreous aspiration underwent radiation therapy. Of the two patients who received radiation only to the orbits and not the brain one subsequently developed CNS lesions. One patient who received CNS and orbital radiation had an ocular recurrence after one year and systemic recurrence 18 months after initial diagnosis (Fig. 4) but was without evidence of CNS spread. In an additional 


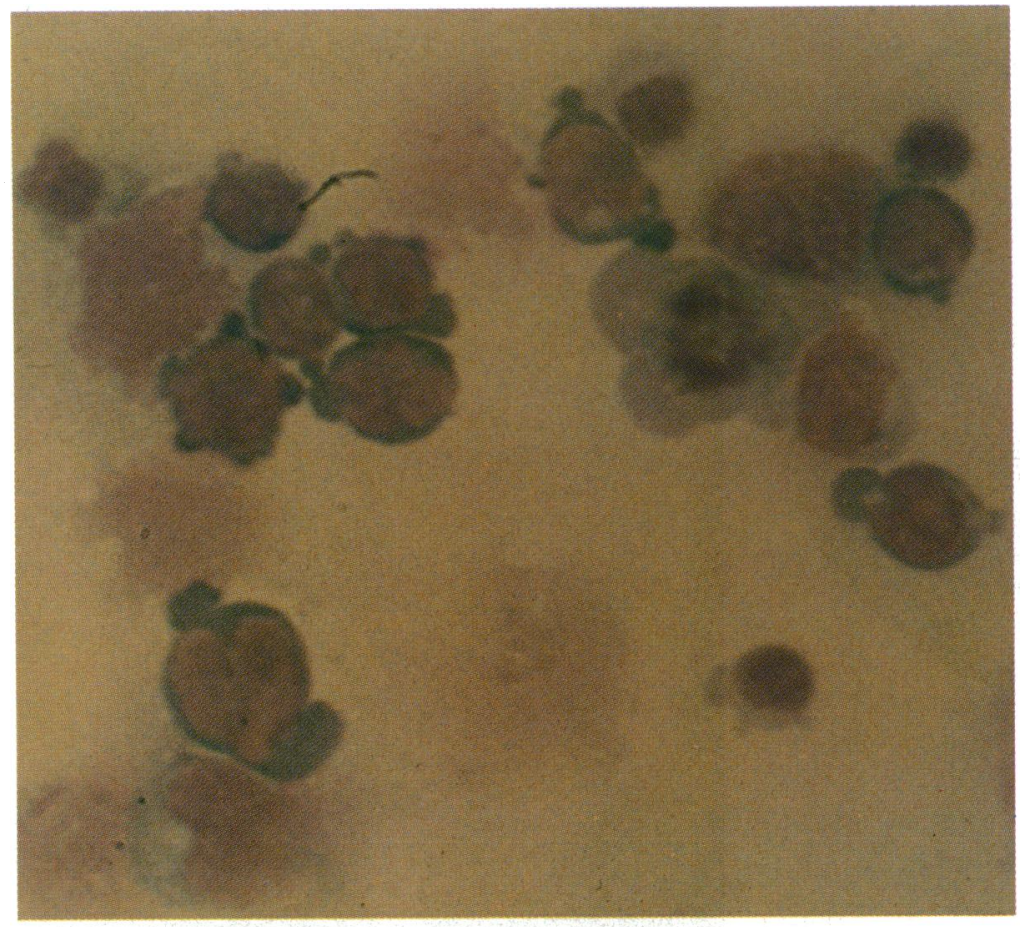

Fig 5 High-power view of vitreous cytospin showing the large atypical cells seen in large cell lymphoma. Giemsa, $\times 1200$.

patient an ocular recurrence and a new brain lesion appeared one and one-half years after ocular and CNS radiation.

In patients who received primary radiation therapy, chemotherapy was reserved for recurrent CNS disease and was effective in one case in causing regression of tumour and preventing death. Two patients received intravenous cytosine arabinoside (Ara-C) as primary therapy for localised ocular disease. At three months follow-up there was no evidence of metastatic disease and partial improvement in ocular findings, though visual acuity remained unchanged.

Our chemotherapy protocol was to give Ara-C $2000-3000 \mathrm{mg} / \mathrm{m}^{2}$ intravenously over a period of one hour. Treatment was repeated every 12 hours for three doses in the hospital and then as single doses repeated at weekly intervals as an outpatient. Toxicity was minimal, consisting of nausea, vomiting, and myelosuppression. No patients showed signs of CNS or cerebellar toxicity.

\section{Discussion}

Our findings confirm many of those noted in smaller series of cases of RCS. Although the mean age of 65 in our series is similar to that in previous reports, one patient was 27 at initial diagnosis. Interestingly, the first patient described with RCS was also $27^{11}$ and so emphasises that, though very unusual, this condition should be thought of in younger patients as well as the elderly.

The most frequent finding in this series was an unexplained posterior and occasionally anterior uveitis. While negative blood studies, chest $x$-ray, and a thorough retinal examination can help to exclude some causes of uveitis, a vitreous aspiration is required for definitive diagnosis. This procedure was performed in all of our patients who consented and in whom the diagnosis was suspected. When present, a characteristic funduscopic picture of multicentric subretinal pigment epithelial lesions ${ }^{1213}$ can help suggest the diagnosis of RCS and was present in half our cases.

Tissue typing is useful in systemic lymphomas both for prognosis and in guiding therapy. Determining whether our cases of RCS were of B-cell or T-cell origin was very difficult given the small volume of vitreous aspirate obtained in individual cases. Only one patient could be typed and this patient had a Tcell lymphoma. Other workers have noted a predominance of B-cell lymphomas, ${ }^{14}$ but all involve a small number of cases. Whether this information will become useful in future in planning treatment of RCS remains to be determined. It is possible that a pars plana vitrectomy would facilitate typing by providing 
Table 1 Data summary of patients with reticulum cell sarcoma seen over the last 10 years

\begin{tabular}{|c|c|c|c|c|c|c|c|c|c|}
\hline \multicolumn{3}{|c|}{$\begin{array}{c}\text { Age/sex Initial visual } \\
\text { acuity }\end{array}$} & \multirow[t]{2}{*}{$\begin{array}{l}\text { Ocular findings at } \\
\text { presentation }\end{array}$} & \multirow{2}{*}{$\begin{array}{l}\text { CNS } \\
\text { lesions at } \\
\text { presenta- } \\
\text { tion }\end{array}$} & \multirow[t]{2}{*}{$\begin{array}{l}\text { Radiation } \\
\text { treatment }\end{array}$} & \multirow[t]{2}{*}{ Chemotherapy } & \multirow[t]{2}{*}{ Recurrence } & \multirow[t]{2}{*}{ Outcome } & \multirow[t]{2}{*}{$\begin{array}{l}\text { Length of } \\
\text { follow-up }\end{array}$} \\
\hline & $O D$ & OS & & & & & & & \\
\hline $55 / \mathrm{F}$ & $20 / 20$ & $20 / 25$ & Vitreous cells, OS & Yes & $\begin{array}{l}40 \text { grey ( } 4000 \\
\text { rad) brain } \\
\text { and OS }\end{array}$ & $\begin{array}{l}\text { Cytoxan, adriamy- } \\
\text { cin, prednisone, } \\
\text { vincristine (used } \\
\text { after recurrence) }\end{array}$ & CNS lesions & Died $1 \frac{1}{2}$ yr & \\
\hline $60 / \mathrm{F}$ & $20 / 30$ & $20 / 25$ & Vitreous cells OU & None & $\begin{array}{l}40 \text { grey brain } \\
\text { and } O U\end{array}$ & None & None & $\begin{array}{l}\text { Visual acuity } \\
\text { unchanged, no metas- } \\
\text { tases }\end{array}$ & 6 mon \\
\hline $27 / F$ & $20 / 15$ & $20 / 50$ & $\begin{array}{l}\text { Vitreous cells, OU; } \\
\text { focal area of RPE } \\
\text { atrophy OS }\end{array}$ & None & $\begin{array}{l}40 \text { grey brain } \\
\text { and } \mathrm{OU}\end{array}$ & $\begin{array}{l}\text { IV Ara-C after } \\
\text { recurrence }\end{array}$ & $\begin{array}{l}\text { CNS after } \\
11 \frac{1}{2} \text { years }\end{array}$ & $\begin{array}{l}\text { 20/20 OU, metastases } \\
\text { improved with Ara-C }\end{array}$ & 18 mon \\
\hline $66 / F$ & $20 / 50$ & $20 / 40$ & $\begin{array}{l}\text { Vitreous cells and } \\
\text { posterior vitreous } \\
\text { detachment OU }\end{array}$ & None & $\begin{array}{l}40 \text { grey brain } \\
\text { and } \mathrm{OU}\end{array}$ & None & None & $20 / 30 \mathrm{OU}$ & 9 mon \\
\hline $55 / \mathrm{F}$ & $20 / 70$ & $20 / 20$ & $\begin{array}{l}\text { Anterior uveitis } \\
\text { OU; Koeppe } \\
\text { nodule OD; retinal } \\
\text { masses/infiltrates } \\
\text { OD; vitreous cells } \\
\text { OU }\end{array}$ & None & $\begin{array}{l}4000 \mathrm{rad} \\
\text { brain and } \\
\text { OU }\end{array}$ & None & None & $\begin{array}{l}\text { 20/20 OU; required } \\
\text { low dose oral predni- } \\
\text { sone for mild persis- } \\
\text { tent uveitis. Repeat } \\
\text { vitreous tap normal } 1 \\
\text { year ago }\end{array}$ & $31 / 2 y r$ \\
\hline $70 / \mathrm{M}$ & $20 / 200$ & $20 / 200$ & Vitreous cells OU & None & 40 grey OU & $\begin{array}{l}\text { Methotrexate, } \\
\text { adriamycin, } \\
\text { prednisone (used } \\
\text { after recurrence) }\end{array}$ & $\begin{array}{l}\text { CNS lesions } \\
\text { in } 6 \text { months }\end{array}$ & $\begin{array}{l}\text { Lost to follow-up, } \\
\text { visual acuity } 20 / 70 \text { OD } \\
\text { and } 20 / 400 \text { OS, CNS } \\
\text { lesions still present } \\
\text { and patient gravely ill }\end{array}$ & $2 \mathrm{yr}$ \\
\hline $64 / F$ & $20 / 70$ & $20 / 200$ & $\begin{array}{l}\text { Vitreous cells OU, } \\
\text { cystoid macular } \\
\text { oedema and retinal } \\
\text { exudates OS }\end{array}$ & None & 20 grey OU & None & None & $\begin{array}{l}20 / 20 \mathrm{OD}, 20 / 70 \mathrm{OS}, \\
\text { no metastases or large } \\
\text { bowel involvement }\end{array}$ & $71 / 2 \mathrm{yr}$ \\
\hline $70 / \mathrm{M}$ & $20 / 70$ & $\begin{array}{l}\text { Finger } \\
\text { counting }\end{array}$ & $\begin{array}{l}\text { Vitreous cells OU, } \\
\text { retinal exudates } \\
\text { OS }\end{array}$ & None & $\begin{array}{l}40 \text { grey brain } \\
\text { and OU }\end{array}$ & None & $\begin{array}{l}\text { Ocular, and } \\
\text { large bowel } \\
\text { involve- } \\
\text { ment, } 1 \\
\text { year. No } \\
\text { CNS lesion }\end{array}$ & $\begin{array}{l}20 / 80 \text { OD, } 20 / 100 \text { OS, } \\
\text { terminally ill }\end{array}$ & $11 / 2 \mathrm{yr}$ \\
\hline $61 / \mathrm{M}^{*}$ & $20 / 30$ & $20 / 30$ & Vitreous cells OU & None & Refused & Refused & & $\begin{array}{l}\text { Died } 6 \text { months with } \\
\text { CNS disease }\end{array}$ & \\
\hline 68/M & $20 / 30$ & $\begin{array}{l}\text { Finger } \\
\text { counting }\end{array}$ & $\begin{array}{l}\text { Coarse vitritis OD, } \\
\text { retinal exudates } \\
\text { OS }\end{array}$ & None & $\begin{array}{l}40 \text { grey brain } \\
\text { and eyes }\end{array}$ & None & None & $20 / 30$ OD and $20 / 50$ OS & $1 \mathrm{yr}$ \\
\hline $66 / M^{*}$ & $20 / 400$ & $20 / 40$ & $\begin{array}{l}\text { Trace anterior } \\
\text { uveitis OU, sub-- } \\
\text { retinal lesions OS, } \\
\text { vitreous cells OU }\end{array}$ & None & None & $\begin{array}{l}40 \mathrm{mg} \text { prednisone } \\
\text { p.o. qD }\end{array}$ & & $\begin{array}{l}\text { Died after } 6 \text { mon } \\
\text { Diagnosed post } \\
\text { mortem }\end{array}$ & \\
\hline $77 / \mathrm{F}^{*}$ & $20 / 30$ & $20 / 200$ & $\begin{array}{l}\text { Vitreous cells OU, } \\
\text { retinal exudates } \\
\text { OS }\end{array}$ & None & None & $\begin{array}{l}40 \mathrm{mg} \text { prednisone } \\
\text { orally as required }\end{array}$ & & $\begin{array}{l}\text { Died after } 6 \text { mon } \\
\text { Diagnosed post } \\
\text { mortem }\end{array}$ & \\
\hline 66/M & $20 / 20$ & $20 / 50$ & Vitreous cells OS & None & None & IV Ara-C & None & Acuity unchanged & 3 mon \\
\hline $62 / \mathrm{F}$ & $20 / 30$ & $20 / 100$ & $\begin{array}{l}\text { Trace anterior } \\
\text { uveitis OS. } 4+ \\
\text { vitreous cells OS }\end{array}$ & None & None & IV Ara-C & None & Acuity unchanged & 3 mon \\
\hline
\end{tabular}

${ }^{*}$ Cases previously reported. ${ }^{+}$

a larger quantity of cells than is obtained by vitreous aspiration.

The rapid demise of all patients who developed central nervous system lesions speaks for the need to prevent spread of this rapidly fatal disease. Radiation therapy causes effective amelioration of ocular symptoms and was usually given in a dosage of $\mathbf{4 0}$ grey
(4000 rad). Although largely empirical, whole brain radiation of 40 grey was also given in the hope of preventing CNS spread of disease. Within the limitations of our follow-up only one patient who was free of CNS lesions at presentation and received prophylactic whole brain radiation subsequently developed CNS metastasis. One additional patient developed 
systemic but not CNS spread of disease. This contrasts with a $75 \%$ incidence ${ }^{15}$ of CNS involvement reported in other series. Our radiation protocol is similar to that used in other centres. ${ }^{16}$

The use of chemotherapy for RCS is less clear. The experience of Char et al. ${ }^{17}$ with three patients given combination chemotherapy, including intrathecal treatment, was favourable. Baumann et al. ${ }^{18}$ successfully treated one patient with intravenous high-dose cytosine arabinoside (Ara-C) who suffered recurrence after radiation therapy. Evidence suggests that Ara-C reaches therapeutic levels in the CSF and vitreous after intravenous therapy. ${ }^{18}$ Our experience with three patients given high-dose intravenous Ara$\mathrm{C}$ has been encouraging. Our one patient with the best response had received radiation therapy primarily. A prospective trial to evaluate the role of systemic high-dose Ara-C in combination with ocular and CNS irradiation as primary therapy needs to be undertaken.

In summary, a high degree of suspicion is needed in patients in whom a chronic posterior uveitis of obscure aetiology persists. Chronic uveitis is unusual in people over 60 , and the differential diagnosis includes sarcoidosis, syphilis, tuberculosis, toxoplasmosis, Whipple's disease, cytomegalovirus infection, metastatic disease, and amyloid disease. The presence of multifocal subretinal lesions is even more suggestive of RCS. If the diagnosis of RCS is entertained, diagnosis can easily be confirmed by means of a vitreous aspiration. It should be remembered that young patients may occasionally be affected with this disease as well. It seems reasonable that such patients with idiopathic posterior uveitis with or without characteristic fundus lesions should undergo diagnostic vitreous aspiration.

We thank Ms Elizabeth Wilkins and Ms DonnaMarie Petrino for assistance in typing the manuscript.

This work was supported in part by an unrestricted grant from Research to Prevent Blindness, New York, NY.

\section{References}

1 Rappaport H. Tumors of the hemopoietic system. Washington,
DC: Armed Forces Institute of Pathology, 1966: section 3, fasicle 8 .

2 Piessens WF, Schur PH, Moloney WC, Churchill WH. Lymphocyte surface immunoglobins: distribution and frequency in lymphoproliferative diseases. N Engl J Med 1973; 288: 17680.

3 Weiter JJ. Case records of the Massachusetts General Hospital. Bilateral uveal disorder unresponsive to corticosteroid therapy. N Engl J Med 1985; 313: 436-43.

4 Simon JW, Friedman AH. Ocular reticulum cell sarcoma. $\mathrm{Br} J$ Ophthalmol 1980; 64: 793-9.

5 Sloas HA, Starling J, Harper DG, Cupples HP. Update of ocular reticulum cell sarcoma. Arch Ophthalmol 1981; 99: 1048-52.

6 Michelson JB, Michelson PE, Bordin GM, Chisari FV. Ocular reticulum cell sarcoma. Arch Ophthalmol 1981; 99: 1409-11.

7 Leff SR, Shields JA, Augsburger JJ, Miller RV, Liberatore B. Unilateral eyelid, conjunctival, and choroidal tumours as initial presentation of diffuse large-cell lymphoma. $\mathrm{Br} \mathrm{J}$ Ophthalmol 1985; 69: 861-4.

8 Rockwood EJ, Zakov ZN, Bay JW. Combined malignant lymphoma of the eye and CNS (reticulum-cell sarcoma). Report of three cases. J Neurosurg 1984; 61: 369-74.

9 Volcker HE, Nauman GO. 'Primary' reticulum cell sarcoma of the retina. Dev Ophthalmol 1981; 2: 114-20.

10 Freeman LN, Schachat AP, Green WR, Knox DL, Michels RG, Green WR. Clinical features, laboratory investigations, and survival in ocular reticulum cell sarcoma. Ophthalmology 1987; 94: $1631-8$.

11 Cooper EL, Riker JL. Malignant lymphoma of the uveal tract. Am J Ophthalmol 1951; 34: 1153-8.

12 Lang GK, Surer JL, Green WR, Finkelstein D, Michels RG, Maumenee AE. Ocular reticulum cell sarcoma. Clinicopathologic correlation of a case with multifocal lesions. Retina 1985; 5: 79-86.

13 Gass JDM, Sever RJ, Grizzard WS, et al. Multifocal pigment epithelial detachments by reticulum cell sarcoma: A characteristic funduscopic picture. Retina 1984; 4: 135-43.

14 Kaplan HJ, Meredith TA, Aaberg M, Keller RH. Reclassification of intraocular reticulum cell sarcoma (histiocytic lymphoma): immunologic characterization of vitreous cells. Arch Ophthalmol 1980; 89: 707-10.

15 Klingele TG, Hogan MJ. Ocular reticulum cell sarcoma. Am J Ophthalmol 1975; 79: 39-45.

16 Margolis L, Fraser R, Lichter A, Char DH. The role of radiation therapy in the management of ocular reticulum cell sarcoma. Cancer 1980; 45: 688-92.

17 Char DH, Margolis L, Neuman AB. Ocular reticulum cell sarcoma. Am J Ophthalmol 1981; 91: 480-3.

18 Baumann MA, Ritch PS, Hande KR, Williams GA, Topping TM, Anderson T. Treatment of intraocular lymphoma with highdose Ara-C. Cancer 1986; 57: 1273-5.

Accepted for publication 21 July 1988. 